\title{
WSPÓLNOTOTWÓRCZY CHARAKTER WIECZERZY PAŃSKIEJ WEDŁUG PIERWSZEGO LISTU DO KORYNTIAN
}

Zasadnicze znaczenie dla naszego opracowania ma fragment 1 Kor 11, 17 - 34. Inny tekst, 1 Kor 10,16 - 22, ma charakter posiłkowy. Pomijamy tutaj problem uzgodnienia relacji ustanowienia Eucharystii u synoptyków i w 1 Kor, jak też zagadnienie rozumienia Eucharystii od strony dogmatycznej. Zwrócimy natomiast uwagę na wpływ sprawowania Wieczerzy Pańskiej na jedność wspólnoty. Pytamy więc: o ile sprawowanie Wieczerzy Pańskiej zobowiązuje wspólnotę do zachowania jedności; oraz: o ile udział w Wieczerzy Pańskiej wplywa na jedność wspólnoty?

Dla zrozumienia wypowiedzi Apostoła konieczne jest poznać jej kontekst. Dlatego na początku zaznajomimy się z sytuacją we wspólnocie korynckiej, szczególnie z jej problemami. Później z fragmentu 1 Kor 11, 17 - 34 wydobędziemy te sformułowania i aluzje, które adresaci winni byli odebrać jako domagające się jedności od całej wspólnoty. Zwróćmy przy tym uwagę na wkład Pawła w takie ujęcie danych, otrzymanych z tradycji dotyczącej sprawowania Wieczerzy Pańskiej. Wreszcie we fragmencie 1 Kor 10, 16 - 22 uwypuklimy treści, które winny pomóc adresatom listu do zrozumienia wymogu jedności wobec tworzonego przez ludzi Kościoła.

\section{KOŚCIÓŁ W KORYNCIE}

Korynt był, po Atenach (Dz 18, 1), kolejnym miastem, które w roku 51 apostoł Paweł nawiedził, mając nadzieję znalezienia wśród jego mieszkańców ludzi gotowych przyjąć naukę Chrystusa. Trudno było o optymizm po generalnym niepowodzeniu i nielicznych nawróceniach w Atenach (Dz 17, $32-34$ ). Zwłaszcza gdy stało się przed miastem o znanej reputacji w całym ówczesnym świecie. Odkryta w 1898 roku synagoga, usytuowana w ważnym dla miasta miejscu, ma wskazywać na zamożność i znaczenie w tym mieście diaspory ży- 
dowskiej ${ }^{1}$. W tej to synagodze najprawdopodobniej rozpoczął Apostoł głoszenie Ewangelii dla tego miasta, tradycyjnie zwracając się naprzód do Izraelitów, choć wśród słuchaczy znaleźli się też Grecy, zapewne prozelici (Dz 18, 4).

Niedawno przybyli z Rzymu małżonkowie Akwila i Pryscylla dali znającemu się, jak i oni, na wyrobie namiotów Apostołowi dach nad głową i pracę, będącą dlań źródłem utrzymania aż do czasu przybycia Sylasa i Tymoteusza $(\mathrm{Dz}$ 18, 2 -3). Gdy ci ostatni przywędrowali z Macedonii, umożliwili Pawłowi wylączne oddanie się nauczaniu, i to nie tylko w szabat (Dz 18, 5).

Rezultatem głoszenia Ewangelii był podział wśród słuchaczy Pawła. Przełożony synagogi, Kryspus, ze swoim domem i część Żydów przyłączyła się do Pawła. Pozosali odrzucili orędzie zbawienia (Dz 18,6-8). Dom przylegający do synagogi, a należący do Tycjusza Justusa, stał się odtąd miejscem zgromadzeń tych, którzy uwierzyli w Pana i przyjęli chrzest (Dz 18, 7). Nowy przełożony synagogi, Sostenes, przy nadarzającej się okazji wystąpił przeciw Pawłowi u nowego prokuratora Achai, Galiona. Wobec braku zainteresowania tego ostatniego sprawami, jego zdaniem wewnątrzżydowskimi, wniesienie skargi zakończyło się jedynie bezkarnym pobiciem powoda $(\mathrm{Dz} 18,18)$.

Po półtorarocznej pracy apostolskiej w Koryncie (Dz 18, 11), udaje się Apostoł do Efezu, potem do Antiochii (Dz 18,18 - 22). W Efezie przybyli z Pawłem Akwila i Pryscylla odkrywają człowieka, który stanie się, obok Pawła, drugą indywidualnością w Kościele korynckim (Dz 18,26). Jest to Żyd, joannita, o imieniu Apollos, wykształcony i „znający świetnie Pisma”. Wsparty listem polecającym udaje się do Koryntu, gdzie działa niezwykle skutecznie, doprowadzając wielu, zwłaszcza Żydów, do wiary w Chrystusa. Kontynuując tak skutecznie działalność Pawła, zyskuje sobie uznanie, przynajmniej u pewnej grupy wspólnoty korynckiej. Wyrazem uznania jest zaproszenie do ponownych odwiedzin Koryntu (1 Kor 16,17). Mimo istnienia w Koryncie grupy wiernych powołujących się na Piotra apostoła, wątpić należy w jego pobyt w tym mieście ${ }^{2}$.

Młody Kościół w Koryncie w efekcie takiej ewangelizacji składał się mimo wszystko z chrześcijan nawróconych z pogaństwa. Judeochrześcijanie, jak się zdaje, stanowili mniejszość ${ }^{3}$. Taki układ nie stanowił powodu do jakichś poważniejszych sporów związanych z pochodzeniem religijno-narodowym. Skład społeczny wspólnoty odzwierciedlał strukturę ówczesnego społeczeństwa. Większość stanowili ludzie z niższych warstw społecznych, jak o tym świadczy choćby wezwanie Apostola na początku jego listu: „Przypatrzcie się, bracia, powołaniu waszemu! Niewielu tam mędrców według oceny ludzkiej, niewielu możnych, niewielu szlachetnie urodzonych" (1 Kor 1,26). Nie brak jednak i ludzi liczących się w społeczeństwie. Do takich niewątpliwie należał Kryspus, da-

\footnotetext{
1 Por. E. DąBrowski, Listy do Koryntian. Wstęp, przekład, komentarz, Poznań 1965, s. 41 n.

2 Por. W. DE BOOR, Pierwszy list do Koryntian, Warszawa 1979, s. 12.

${ }^{3}$ Por. E. DĄiRowsKi, jw., s. 47.
} 
wny przełożony synagogi, czy Tycjusz Justus, właściciel domu przylegającego do synagogi, zapewne obszernego, skoro nadawał się do zgromadzeń (Dz 18, 7), czy też Stefanas, ochrzczony przez samego Pawła $(1 \text { Kor } 1,16)^{4}$.

Istniejące różnice społeczne stały się powodem nadużyć zdarzających się nawet w czasie zgromadzeń dla spożywania Wieczerzy Pańskiej (1 Kor 11, 22). Ubodzy i niewolnicy doznawali upokorzenia, gdy przychodząc później, zastawali stoły puste za sprawą przychodzących wcześniej zamożniejszych członków wspólnoty $(1$ Kor 11, 21). Szukanie sprawiedliwości przed trybunałami pogańskimi, zamiast znoszenia niesprawiedliwości i ponoszenia szkody (1 Kor $6,8)$ w kontekście katalogu grzechów (1 Kor 6,9-10), pozwala domyślać się i tutaj sporów w sprawach materialnych. Nie wymaga przy tym Apostoł zniesienia wszelkich różnic społecznych i majątkowych, ale wskazując względność wszelkich różnic wobec rzeczywistości przynależności do Chrystusa (1 Kor 7, 21 - 23), zachęca do pozostania w takim stanie, w jakim zastało człowieka powołanie $(1 \mathrm{Kor} 7,20.24)$. Nie wymaga też Paweł wspólnoty dóbr, ale wzywa wszystkich do odkładania co tydzień dobrowolnej sumy dla zapowiedzianej zbiórki na rzecz potrzebującego Kościoła w Jerozolimie (1 Kor 16, 2).

Powszechnie aprobowana w Koryncie rozwiązłość, usankcjonowana prostytucją sakralną, w połączeniu $\mathrm{z}$ niezrozumieniem wolności głoszonej przez Pawła $(1$ Kor 6,$12 ; 10,23)$ wydaje straszliwe owoce: nie zostaje potępiony przez wspólnotę związek kazirodczy (1 Kor 5, 1 - 2) oraz naiwne uzasadnianie potrzeby zaspakajania potrzeb seksualnych w sposób równie wolny, jak potrzeb żołądka ( 1 Kor 6,12-13).

Problemem powszednim chrześcijan, zwłaszcza tych pochodzących z pogaństwa, były naturalne więzi z ludźmi pozostającymi poza Kościołem. Apostoł nie wymaga „opuszczenia tego świata” $(1$ Kor 5,10$)$, ale jest świadom zagrożenia wypływającego $\mathrm{z}$ obcowania $\mathrm{z}$ poganami, choćby przez udział we wspólnych posiłkach, mających często charakter kultyczny, a więc bałwochwalczy. Oczywiście proste spożywanie posiłku, choćby ofiarowanego niegdyś bożkom, nie jest bałwochwalstwem, mimo że staje się niedozwolone, gdy może zgorszyć brata o słabym sumieniu (1 Kor 8,10-13). Natomiast czymś nie do pomyślenia jest świadomy udział chrześcijanina w uczcie mającej jednoznacznie bałwochwalczy charakter (1 Kor 10, 20-21).

Problemem zasadniczym, który powraca nieustannie w różnych odmianach, jest jedność wspólnoty. Wspólnota bowiem, mimo pozostawienia Sylasa dla jej kierowania ${ }^{5}$, przeżywa rozbicia $(1$ Kor $1,11-12)$. Rozdziały ujawniają się nie tylko w niedostrzeganiu bliźniego przy uczcie, ale także w separatystycznym opowiadaniu się za takim czy innym duszpasterzem $(1$ Kor 1,12$)$. Z powodu niedojrzałego traktowania tych, których Apostoł określa „sługami Chrys-

\footnotetext{
4 Por. tamże.

5 Por. tamże, s. 48 n.
} 
tusa i szafarzami tajemnic Bożych" $(1$ Kor 4,1$)$, adresaci są nazwani przez Pawła ludźmi „cielesnymi, niemowlętami w Chrystusie” (1 Kor 3, 1). Pyta więc Paweł przeżywającą wielorakie podziały wspólnotę: „Czyż Chrystus jest podzielony?” (1 Kor 1, 13). Grozi tym, którzy są sprawcami podziałów: „Jeżeli ktoś zniszczy świątynię Boga, tego zniszczy Bóg. Swiątynia Boga jest święta, a wy nią jesteście” ( 1 Kor 3.17). Wskazuje na podstawę jedności: „Podobnie jak jedno jest ciało, choć składa się z wielu członków, a wszystkie członki ciała, mimo iż są liczne, stanowią jedno ciało, tak też jest z Chrystusem. [...] Wy przeto jesteście Ciałem Chrystusa i poszczególnymi członkami” (1 Kor 12, 12. 27).

WYMAGAJĄCA UCZTA (1 KOR 11, 17-34)

Poza ewangeliami synoptycznymi jedynie pierwszy List do Koryntian przynosi słowa ustanowienia Eucharystii. Pawłowe dane nie są jednak prostą relacją z przebiegu Ostatniej Wieczerzy, ani też nie stanowią całościowego zapisu tego, jak przebiegała Wieczerza Pańska w Koryncie w latach pięćdziesiątych pierwszego wieku. Co do tej ostatniej możemy stwierdzić, iż składała się z uczty miłości oraz z uczty eucharystycznej. W czasie pierwszej części uczestnicy w atmosferze miłości spożywali przyniesione przez siebie pokarmy, dzieląc się z innymi i przygotowując do uczty Pana, w czasie której spożywało się już Ciało i Krew Pańską. Porządek taki miał walor wychowawczy. W czasie pierwszej uczty przez wspólne zasiadanie do posiłku, wspólne spożywanie i dzielenie się naturalnym pokarmem winna się zawiązać wspólnota. Ta wspólnota w drugiej uczcie miała być wzmocniona w swojej jedności przez sakramentalne działanie Pana. Chrystusowe działanie zakładało uprzednie zaangażowanie całej wspólnoty. Kto nie był zdolny do przeżycia wspólnoty na poziomie naturalnym, nie mógł być zdolny do przeżycia jedności wspólnoty przez działanie Chrystusa poprzez wspólne spożywanie Wieczerzy Pańskiej.

Paweł w ocenie postępowania korynckiej wspólnoty idzie dalej. Powtrzanie słów i gestów Chrystusa z Ostatniej Wieczerzy obraca się przeciw tym uczestnikom, którzy grzeszą przeciw braciom i to w sposób zdawałoby się tak mało istotny dla Eucharystii, jak wcześniejsze rozpoczęcie Wieczerzy. Gdy grzeszy się przeciw braciom, nie ma spożywania Wieczerzy Pańskiej (1 Kor 11, 20), a spożywanie Ciała i Krwi Pana powoduje zaciągnięcie winy (1 Kor 11, 29. 34). Taka ocena podyktowana jest traktowaniem przez Pawła Wieczerzy Pańskiej jako jednej uczty, przebiegającej w dwóch etapach: uczta miłości i uczta eucharystyczna.

Konkretne więc nadużycia, zdarzające się w czasie świętej uczty, są powodem wypowiedzi Pawła. Oceny faktów dokonuje Apostoł nie tylko swoją powagą, lecz także odwołując się do tradycji otrzymanej od Pana, a dotyczącej 
sprawowania Wieczerzy Pańskiej. Tradycji znanej i respektowanej przez wspólnotę koryncką. Słowa Chrystusa z Ostatniej Wieczerzy stanowiące rdzeń tego przekazu, a zawierające już sformułowania piętnujące zachowanie Koryntian, zostają jeszcze oprawione w przemyślane pouczenia, zawierające dosadną ocenę postępowania wspólnoty. W dalszej części opracowania wydobędziemy te słowa, sformułowania i aluzje będące wezwaniem wspólnoty do przeżywania jedności oraz treści teologiczne, wskazujące wpływ spożywania Wieczerzy Pańskiej na jedność.

\section{Synerchomai}

Słowo to użyte zostało przez św. Pawła pięć razy i to właśnie w naszym urywku (1 Kor 11, 17 - 34). Przedrostek syn-' oraz kontekst użycia go stanowi klucz do zrozumienia omawianego fragmentu Pawłowego tekstu. Słowo to wyznacza w nim strukturę koncentryczną: A B C B A. Schemat omawianego fragmentu według tej struktury przedstawia się następująco:
SKUTEK
ZEBRANIE SIE
A (w. 17)
nie na lepsze, ale ku (synerchesthe) gorszemu
B (w. 18)
C (w. 20)
B' (w. 33)
abyście się nie ku nerchomenoi) potępieniu
gdy schodzicie się ra- zem (synerchomenon)
gdy się zbieracie (sy- nerchomenon)
gdy się zbieracie (sy-
$A^{\prime}$ (w. 34)
zbierali (synerchesthe)
CHARAKTER ZE- BRANIA
PROBLEM JEDNOŚCI
jako Kościół nie ma u spory (uchybie- was spożywania Wie- nia $\mathrm{z}$ ww. 21 - czerzy Pańskiej by 22) spożywać poczekajcie je- dni na drugich

Widzimy się, że w części centralnej występuje twierdzenie zdecydowanie negatywne: „Nie ma u was spożywania Wieczerzy Pańskiej” (1 Kor 11, 20). Jako uzasadnienie dla tej tezy zgromadził autor wiele określeń negatywnych, sprzeciwiających się idei Wieczerzy Pańskiej: „Każdy wcześniej zabiera się do własnego jedzenia”; ,jeden jest głodny, podczas gdy drugi nietrzeźwy”; „znieważać Boże zgromadzenie”; „zawstydzać tych, którzy nic nie mają” (por. 11, 21 - 22). Nieprzypadkowo po fragmencie centralnym i jego eksplikacji $(11,2 \theta$ -22) św. Paweł przytacza argument najtrudniejszy do podważenia: tradycję otrzymaną od Pana, którą stanowi relacja z ustanowienia Eucharystii $(11,23$ 25).

W zdaniach według struktury sąsiadujących ze składnikiem centralnym odnajdujemy bliższe określenie owego wspólnego „gromadzenia się”. Wiersz 18. 
precyzuje, że zbierają się (synerchomenon) „w Kościól” (en ekklesia), a w. 33 dodaje: „aby spożywać” (eis to fagein). W tych elementach znajdujemy także inne dane dotyczące jedności, nawzajem sobie odpowiadające. Wiersz 18. wskazuje na zdarzające się między uczestnikami spory (schismata), a odpowiadający mu w strukturze w. 33 daje zalecenie: „poczekajcie jedni na drugich” (allelous ekdechesthe).

W zdaniach stanowiących elementy skrajne naszej struktury autor umieścił wypowiedzi mówiące o skutku „zgromadzenia się”. Wiersz 17. zawiara naganę, iż schodzą się „na gorsze” (eis to hesson), a przy tym wskazany jest alternatywny skutek: „na lepsze”, który nie jest udziałem adresatów (ouk eis to kreisson). Drugie ze zdań spinających naszą strukturę wyraża życzenie, aby te zebrania nie sprowadziły na uczestników potępienia (w. 34).

Tak więc nie wystarczy zebrać się razem jako Kościól dla spożywania Wieczerzy Pańskiej, by ona miała miejsce. Trzeba jeszcze wykluczyć wszelkie podziały i grzechy przeciw miłości braterskiej, które sprawiają, że uczta przestaje być „ucztą Pana”, a staje się ucztą egoistyczną. Tak należy rozumieć przeciwstawienie „idion deipnon” i „kyriakon deipnon” $(11,20-21)^{6}$. Istotnym więc rysem tych liturgicznych spotkań ma być przeżycie jedności i miłości braterskiej.

\section{„Ciało moje za was”}

O ile tak przemyślane użycie czasownika synerchomai pochodzi od Apostoła, o tyle formuła wypowiadana nad chlebem w czasie sprawowania Eucharystii została przekazana tradycją sięgającą samego Pana. Adresaci listu winni i tę aluzję w słowach Chrystusa odczytać jako wezwanie do jedności.

Komentatorzy zwracają uwagę, iż Chrystus mówiąc „to” nad chlebem i określając go jako „Ciało moje za was”, miał na myśli streszczenie całego poprzedniego działania. Użyte tu słowo „Ciało” oznacza po prostu osobę Jezusa wyrażającą się poprzez ciało wobec świata. Kontekst śmierci oraz przyimek hyper wskazują na wymiar tego ciała jako „daru z siebie” i to daru ,zamiast” nich, a zarazem na „ich korzyść”. Dar ten dany jest w formie pokarmu, aby mogli żyć ${ }^{7}$.

Dar ten, dany uczestnikom uczty, zakłada istnienie wspólnoty, a nawet zażyłości między uczestnikami. I nie chodzi tylko o wspólnotę w obrębie spożywających, albowiem występujące w 1 Kor 11,24 „za was” (por. Łk 22, 19) w innych relacjach z Ostatniej Wieczerzy zastąpione jest przez „za wielu”, a więc „za wszystkich”. Interpretując nasz tekst w świetle Iz 53, $10-12$, można od-

6 Por. P. Neuenzeit, Das Herrenmahl, München 1960, s. 189.

${ }^{7}$ Por. X. L. Dufour, Corps du Christ et Eucharistie selon saint Paul, [w:] Le corps et le Corps du Christ dans la première Épître aux Corinthiens, Paris 1983, s. 242 n. 
czytać śmierć Jezusa jako oddanie się za wszystkich, „by rozproszone dzieci Boże zgromadzić w jedno" (J 11, 52) ${ }^{8}$. Przez nakaz powtarzania słów i gestów z Ostatniej Wieczerzy (1 Kor 11, 24 - 25) Jezus pragnie być obecny w kolejnych pokoleniach chrześcijan, sprawujących to misterium. Pragnie być rozpoznany w każdej wspólnocie, w każdym czasie i w każdym miejscu, aby przypominać, że biorą Jego Ciało za nich wydane i im dane, by stanowili jedno? 9

\section{Nowe Przymierze we Krwi}

Dla zrozumienia tej, pochodzącej również z przekazu tradycji wypowiedzi, trzeba spytać o przymierze „stare”. Jest nim zawarte w czasie wędrówki przez pustynię przymierze synajskie ( $\mathrm{Wj} 24)$. Zostaje ono zawarte przez przedstawicieli Izraela przy aklamacji całego ludu: „Wszystkie słowa, jakie powiedział Pan, wypełnimy" (Wj 24,3). Treścią przymierza są słowa wypowiedziane przez Boga, a przekazane ludowi przez Mojżesza. Znakiem zawarcia przymierza z całym narodem jest dwanaście stel oraz wylanie krwi na ol tarz i na zgromadzoną społeczność ( $\mathrm{Wj} 24,4-8)$. To przymierze zawarte niegdyś z konkretnym pokoleniem Izraela obejmuje jednak lud Boży wszystkich czasów. Konstytuuje się bowiem wtedy ponadczasowy i ponadprzestrzenny lud Boży ${ }^{10}$.

Nawiązując do tego, podstawowego dla Izraela, przymierza i patrząc w przyszłość, prorok Jeremiasz zapowiada przymierze „nowe” (cały rozdział 31). Niewierność narodu wybranego i nowa inicjatywa ze strony Boga to fakty. Istota przymierza, a więc Prawo i wzajemna przynależność do siebie Boga i ludu mają pozostać niezmienione. Nowością ma być powszechność i większa prostota tego nowego przymierza. Skutkiem zaś puszczenia w niepamięć dotychczasowych grzechów oraz lepsze poznanie woli Jahwe ${ }^{11}$.

Ale formuła nasza nawiązuje także do czwartej pieśni o słudze Jahwe, gdzie „przymierzem dla ludzi” $i$ to ustanowionym przez Boga ma być sam sługa Jahwe (Iz 42, 6; 49, 8). Tu też chodzi przede wszystkim o bliskość Jahwe i doskonalszą Jego znajomość ${ }^{12}$.

To „nowe Przymierze” we Krwi Jezusa jest nawiązaniem do przymierza synajskiego i wypełnieniem zapowiedzi proroków. Jezus, jako nowy Mojżesz, zawiera to przymierze między Bogiem a tymi, którzy stanowić będą nowy Lud Boży. Ten ostatni gromadzi się na Ostatnią Wieczerzę również w liczbie dwunastu, „stosownie do liczby pokoleń” Izraela (por. Wj 24,4). Treścią nowego Przymierza jest przykazanie miłości. Dlatego też św. Jan w swojej Ewangelii

${ }^{8}$ P. NEUnzeit, jw., s. 159 n.

9 Por. J. KUDASIEWICZ, Elementy eklezjalne $w$ tekstach ustanowienia Eucharystii, „Studia Theologica Varsaviensia" 18: 1980 z. 2 s. 38.

10 Por. tamże, s. $41 \mathrm{n}$.

11 Por. A. JANKOWSKI, Biblijna teologia przymierza, Katowice 1985, s. 66.

12 Por. tamże, s. 105. 
w miejsce przekazu o ustanowieniu Eucharystii daje relację o umyciu nóg Apostołom (J 13, 1 - 11) oraz słowa wyjaśniające gest, a także proklamację przykazania „nowego" (J 13, 34 - 35). Dlatego to zachowanie wspólnoty korynckiej, rażąco sprzeczne z tym przykazaniem, spotyka się z taką naganą Apostola.

W przymierzu „nowym” krew zwierząt zostaje zastąpiona Krwią Chrystusa. Istotną rolę w zawarciu przymierza spełnia także uczta. W czasie tej uczty Krew zostaje podana w kielichu i spożyta. To wskazuje na wnętrze człowieka, jako obszar związany z przymierzem. Wspólne spożywanie kielicha konstytuuje nowy Lud Boży, a nakaz powtarzania wieczerzy ma na celu przypominanie przymierza kolejnym pokoleniom oraz odnawianie je w sercach ${ }^{13}$.

Wartość i obowiązywalność tego nowego Przymierza podnosi formuła „en to emo haimati”, będąca według biblijnych paralel synonimem śmierci zadanej przemocą. Mocą takiej Krwi zawarte jest nowe Przymierze, konstytuuje się i umacnia Kościół jako przestrzeń życiowa, a zarazem sposób życia wobec Boga dla tych, którzy wierzą w Chrystusa ${ }^{14}$. Tę aluzję również winni odczytać adresaci listu.

\section{„Gtosić śmierć Pana”}

Każde spożywanie na sposób Wieczerzy Pańskiej jest „głoszeniem śmierci Pana” $(1$ Kor 11,26$)$. Niezależnie od tego, jak przetłumaczymy zwrot „archis hou elthe" 15 , można powiedzieć, iż to głoszenie jest ograniczone czasowo momentem powtórnego przyjścia Chrystusa. Użyty w w. 26 przez Pawła czasownik „kataggello”, mający w Nowym Testamencie zawsze sens sakralny, nie oznacza zwykłego przypomnienia jakiejś prawdy czy polemiki z oponentami, ale wskazuje na uroczystą proklamację, w tym wypadku o śmierci Chrystusa i o jej wymiarze zbawczym ${ }^{16}$.

Spożywanie pokarmu jedynie dla zaspokojenia głodu zostaje przeniesione do domów (1 Kor 11, 22. 34). W czasie zaś zgromadzenia się w Kościół dla spożywania Wieczerzy Pańskiej ma mieć miejsce uczta o charakterze proklamacji. Treścią tej proklamacji ma być śmierć Pana ${ }^{17}$. Ta właśnie proklamacja poprzez spożywanie Wieczerzy Pańskiej ma dać nowy sposób obecności Chrystusa. W czasie od odejścia Chrystusa do Ojca aż do momentu paruzji może On być obecny dzięki „głoszeniu” Jego śmierci przez wspólnotę ${ }^{18}$. Trzeba tu jeszcze

${ }^{13}$ Por. J. Kudasiewicz, jw., s. 42 n.

14 Por. P. NeUzeIt, jw., s. 161.

15 Zwrot ten można przetłumaczyć także: „aż przyjdzie Pan”, lub — ,aby przyszedł”.

16 Por. A. JANKOWSKI, jw., s. 115.

17 Por. J. Calloud, Le Repas du Seigneur. La communauté corps du Christ. Analyses semiotiques, [w:] Le corps et le Corps du Christ..., s. 120.

18 Por. tamże, s. 124. 
dodać, że Kościół przestałby być sobą, to znaczy tym, czym chciał go uczynić Chrystus, gdyby sprzeniewierzył się poleceniu „głoszenia śmierci Pana"19. W związku z tym można mówić o trzech sposobach obecności Chrystusa pośród ludzi:

tej nocy, kiedy zostat wy- ilekroć spożywacie albo aż przyjdzie... dany... pijecie...

PAN BYŁ

spożywanie i picie, nakaz powtarzania

\section{WSPÓLNOTA GŁOSI SMIERĆ PANA}

spożywanie i picie
PAN PRZYJDZIE

oczekiwanie

J. Calloud w ramach interesującj analizy, stawiając pytanie o stosunek „słowa” do „ciała” i o umiejscowienie „słowa” w „ciele”, rozważa dwa skrajne przypadki będące dwoma różnymi skutkami „słowa” dla jedności „ciała”20. I tak słowo może pełnić funkcję destrukcyjną: każdy członek może chcieć być całym ciałem. Ale też słowo może być wypowiedziane przez całe ciało, złożone z wielu członków. I wtedy ciało umacniane jest w swojej jedności. Staje się ono przestrzenią wolnego i poprawnego krążenia słowa. Jawi się jako ciało osoby, jednej osoby, ciało żywe. Tak więc i polecenie „głoszenia śmierci Pana” może być odczytane jako wezwanie do jedności.

\section{KONSEKWENCJE UCZTY (1 Kor 10, 16-22)}

Powodem wypowiedzi Pawła, którą chcemy obecnie zbadać (1 Kor 10, 16 -22), nie są nadużycia w czasie Wieczerzy Pańskiej, ale niedostrzeganie konsekwencji i uczestnictwa w niej. Dlatego ten fragment bardziej zwraca uwage na skutki niż na wymagania wobec uczestników.

Jedność przez ottarz

Perykopę 1 Kor $10,14-22$ można przedstawić następująco ${ }^{21}$ : strzeżcie się bałwochwalstwa $14-15$

Kielich

i udział $16-17$

jedność

$\mathrm{z}$ ołtarzem 18 będziemy pobudzali 22 Pana do zazdrości? Kielich Pana 21 kielich demonów ofiarować $w$ jedności $20 \mathrm{z}$ demonami

19 ofiara i bożek są niczym

${ }^{19}$ Por. W. KUYNIEWICZ, Nasza pascha z Chrystusem. Zarys chrześcijańskiej teologii paschalnej, t. 2, Lublin 1987, s. 497.

21 Por. X. L. Dufour, jw., s. 229. 
W ramach tego chiazmu podobieństwo między zestawionymi stołami nie odnosi się to takiego czy innego daru ofiarowanego, ale do skutku, jaki wywołuje uczestnictwo w uczcie kultowej. Skutkiem bowiem jest więź uczestników uczty z tą potęgą, przy której ołtarzu się zasiada 22 .

Św. Paweł zakłada w swoim pouczeniu udział adresatów w uczcie przy stole czy inaczej - przy ołtarzu Pana, gdzie wchodzi się w więź z Nim poprzez kielich i chleb (1 Kor 10, 16 - 17). Dlatego to jako niedopuszczalne uważa próbę godzenia dwóch kultów i dwóch zjednoczeń: z Panem i demonami (1 Kor 10, 21). Kult bowiem pogan jest oddawaniem czci demonom (1 Kor 10,19-20).

Nas interesjuje związek spożywania Wieczerzy Pańskiej z jednością wspólnoty. Związek taki istnieje. Więź bowiem, jaka się wytwarza poprzez zasiadanie przy stole Pana, dotyczy nie tylko relacji: Pan - chrześcijanin, ale także: chrześcijanin - chrześcijanin, jeżeli tylko zasiadają przy stole tego samego Pana. Ta więź zaciągana wobec Pana i braci jest wymagająca. Nie może być tylko zewnętrzna, formalna. Właśnie faktycznej i wewnętrznej jedności w Koryncie sprzeciwiało się aspołeczne zachowanie części członków wspólnoty, którzy stół Pana potraktowali jako stół własny, a dary mające być sposobnością do okazania miłości i jedności ukazały prawdę o jedności pozornej. Jedność pozostała jakó propozycja Pana, przez część wspólnoty przyjęta w sposób czysto zewnętrzny ${ }^{23}$.

Ta jedność przez stół musi być weryfikowana, także ze względu na ogromne znaczenie tego sposobu wyrażania jedności. Pisze o tym Apostoł wcześniej. Nie wolno zasiadać do stołu z kimś, kto uważa się za brata, a jest faktycznie grzesznikiem (por. 1 Kor 5, 11). Człowieka takiego należy usunąć ze wspólnoty, by jego grzechy nie kalały całej łączącej się z Panem świętej społeczności (por. 1 Kor 5, 4-8.13).

\section{Motyw jednego chleba}

Dla Pawła, faryzeusza i spadkobiercy tradycji rabinistycznej, chleb zawsze oznaczał coś więcej niż pokarm najbardziej powszedni. Chleb bowiem w myśli semickiej kojarzy się w sposób naturalny z życiem i tym, co najbardziej podstawowe w życiu: $\mathrm{z}$ przekazywaniem życia, $\mathrm{z}$ trudem, cierpieniem. Autorzy natchnieni przez zwroty zawierające słowo "chleb" charakteryzują człowieka. I tak „chleb przygnębienia” czy „chleb łez” albo „chleb popiołu” spożywa człowiek dotknięty nieszczęściem. „Chleb nieprawości” lub „chleb kłamstwa” określa grzesznika. Zaś „spożywanie tego samego chleba” oznacza zażyłość, przyjaźń, wspólnotę 24 .

${ }^{22}$ Por. tamże, s. 228 n.

${ }^{23}$ Por. K. KerTElge, Abendmahlgemeinschaft und Kirchengemeinschaft im Neuen Testament und in der Alten Kirche, [w:] F. HAhn, K. KeRTELge, R. SCHnACKEnBurg, Eincheit der Kirche. Grundlegung im Neuen Testament, Freiburg im Br. 1979, s. 104. 
Paweł przypomina Koryntianom element istotny dla Wieczerzy Pańskiej, jakim było „łamanie chleba”. Już sam ten zwrot kojarzy się ze wspólnotą (por. występującą w kontekście wspólnoty wypowiedź Dz 2, 42) i stanowi wymowny znak dla wyrażenia, a zarazem wezwania do jedności. Jak bowiem połamany chleb, stanowiący niegdyś całość, może nadal — po złożeniu — stanowić jeden chleb, tak jest i z ucztującą wspólnotą. Zbiera się „wielu”, by przez wspólne „łamanie chleba” wyrazić swoją jedność, a zarazem przypomnieć sobie wezwanie do jedności. Wyraża tę ideę nieco późniejszy tekst Didache (nr 9): „Jak ten łamany chleb był rozsiany po górach i zebrany stał się czymś jednym, tak niech się zbierze Twój Kościól z krańców ziemi do Twego Królestwa”25.

Użyty w wierszu 10, 17 nie musi być rozumiany dosłownie jako rzeczywiście tylko jeden chleb, bo trudno przypuścić, by spożycie dwóch bochenków przez ucztujących miało stworzyć dwie wspólnoty. Raczej idzie o wspólne spożywanie te g o chleba. Ono tworzy wspólnotę i zobowiązuje do życia w jedności, nie pozwala też na występowanie uczestników przeciw sobie (por. Ps 41, 10). Za tym, że autorowi listu chodziło o wskazanie motywu jedności przez widzialny znak, jakim jest spożywanie tego samego (niekoniecznie jednego) chleba, przemawia i podwójne przeciwstawienie, jakie spotykamy w 10, 17: ,jeden - liczni” oraz „ten sam — wielu”.

Motywacja jedności wspólnoty ze względu na wspólne spożywanie jednego chleba staje się jeszcze bardziej wymowna, gdy przechodząc na inny poziom, widzi się ów ,jeden chleb” jako Ciało Chrystusa, zaś wspólnotę ucztującą jako Kościół - Ciało Chrystusa. Można wtedy powiedzieć, że wspólnota przez każde spożywanie chleba eucharystycznego doświadcza swojego „Bycia-CiałemChrystusa" (Leib-Christi-Sein) ${ }^{26}$, bo też chleb-Ciało jest wymownym wezwaniem a zarazem podstawą dla jedności wspólnoty - Ciała.

W przyjętym przez wspólnotę koryncką porządku Wieczerzy Pańskiej (uczta miłości i uczta eucharystyczna) oraz w dwupoziomowym pojmowaniu chleba można dopatrzyć się swoistej pedagogii. Uczta polegająca na braterskim spożywaniu chleba winna była przygotować i zweryfikować uczestników dla uczty na innym poziomie. Kto nie pojmowal poziomu naturalnego, nie był zdolny pojąć nadprzyrodzonego.

${ }^{24}$ Por. D. SesBoué, Chleb, [w:] Stownik teologii biblijnej, red. X. L. Dufour, Poznań 1985, s. $118 \mathrm{n}$.

${ }^{25}$ H. Muckermann, Sakramenty wiary, Kraków 1970, s. 135 (tł. W. Ka ni a).

${ }^{26}$ K. Kertelge, jw., s. 102. 


\section{Koinonia}

Konsekwencją wspólnego spożywania chleba jest uczestnictwo (koinonia) w Ciele i Krwi Pana (1 Kor 10,17). Użyta tu nietypowa konstrukcja („,koinonia" $\mathrm{z}$ dopełniaczem w odniesieniu do osób) wskazuje na ścisłe zjednoczenie uczestnika „łamania chleba” z Chrystusem. Chleb i kielich są swoistymi „narzędziami" - czy sposobem nawiązania komunii z Chrystusem. Ta komunia chrześcijanina z Chrystusem, zapośredniczona w „akcji eucharystycznej”, zachowuje odrębność osób. Tę jedynie pośredniczącą funkcję pokarmu i napoju sygnalizuje już występujący wcześniej w naszym liście passus odnoszący się do Izraela historycznego, z którego wynika, iż „nasi ojcowie” spożywali pokarm duchowy i pili duchowy napój, ale skałą był Chrystus $(10,3-4)^{27}$.

Konsekwencją wielu poszczególnych komunii z Panem jest komunia między uczestnikami. Stanowi ona rezultat wspólnego uczestniczenia w „łamaniu chleba” i „błogosławieniu kielicha”. Wniosek nasz wspiera użycie przez św. Pawła słowa koinonia w kontekście wspólnoty obejmującej odległe od siebie geograficznie Kościoły, a wyrażanej przez kolektę na rzecz potrzebującego Kościoła w Jerozolimie ( $\mathrm{Rz} 15,26 ; 2$ Kor 8, 4). Rzecz interesująca, iż zachęta Pawła do odkładania daru na rzecz potrzebujących braci $(1$ Kor 16, 2) związana jest $\mathrm{z}$,pierwszym dniem tygodnia”. Czy nie jest to ślad wyrażania w tak konkretny sposób owej koinonii w czasie sprawowania Eucharystii w tym właśnie dniu?

Wymagania stawiane uczestnikom Eucharystii ze względu na zaistniałą komunię z Panem oraz między uczestnikami trafnie wyraża E. Haulotte, cytowany przez G. Marteleta: „Jeżeli komunia ze Zmartwychwstałym miała być prawdziwa [...], to wymagała ona w razie potrzeby nawet sprzedania pola i domu. Czy ci, którzy posiadają pewne dobra w nadmiarze, mogą zachowywać je z lekkim sercem, skoro chociażby jeden członek Chrystusa - jednostkowy lub zbiorowy - cierpi w niedostatku? Czy to nie byłoby zerwaniem 'komunii'?"28

\section{Tworzyć jedno Ciało}

Najgłębszą motywację jedności wspólnoty zostawiliśmy na koniec. Chodzi o bogate w treści i paralele stwierdzenie: „my, liczni, tworzymy jedno Ciało” (1 Kor 10,17). Słowo 'ciało' (soma), występujące w dwu kolejnych wierszach $(20,16$ - 17) oznacza za pierwszym razem „Ciało Chrystusa”, w którym uczestnicy „czynności eucharystycznych” mają udzial, w drugim zać 'ciało', które sami stanowią. Elementem wspólnym obu wersetów jest komunia. Przy

${ }^{27}$ Por. X. L. Dufour, jw., s. 233.

28 Zmartwychwstanie, Eucharystia, człowiek, Warszawa 1976, s. 210 n. 
czym komunia wertykalna (udział w Ciele i Krwi Pana) pociąga za sobą komunię horyzontalną („my, liczni, tworzymy jedno Ciało”) ${ }^{29}$.

Umieszczenie obok siebie słowa soma w znaczeniu eucharystycznym i eklezjalnym nie jest przypadkowe. Dla Pawła bowiem istnieje tylko jeden Chrystus, który jest Bogiem ponad wszystkim (por. 1 Kor 15, $27-28$; Rz 9, 5). Nasze zaś rozróżnienia: Ciało Chrystusa — eklezjalne czy eucharystyczne — oraz zdziwienie wobec gwałtownego, zdawałoby się, przejścia od jednego znaczenia do drugiego, jest obce myśli biblijnej ${ }^{30}$.

To ,jedno Ciało” określa nam bliżej, sformułowany w kategoriach hellenistycznych, rozdział dwunasty, gdzie Apostoł poprzez „Ciało Chrystusa” oraz „poszczególne członki” definiuje Kościół (1 Kor 12, 27). J. Schlosser ${ }^{31}$ proponuje wiersz 12, 27 przetłumaczyć następująco: „Jesteście Ciałem, Ciałem Chrystusa", co ma oddać ukryte w tym wersecie dwie warstwy jedności w Ciele, którym jest Kościól. Pierwszą byłaby solidarność między członkami (topos hellenistyczny), drugą zaś zakorzenienie ciała eklezjalnego w samym Chrystusie. Z punktu widzenia parenetycznego „soma Christou” oznaczałoby więc jedność na sposób ciała, z punktu zaś teologicznego i ontologicznego wskazywałoby na ciało, które jest Chrystusowe. Ciało to, będące Ciałem Chrystusa, ,nie rodzi się przez zjednoczenie chrześcijan między sobą, ale chrześcijanie są włączani do Ciała, które już istnieje" 32 .

Uwzględniając w naszym spojrzeniu na Ciało Chrystusa typologię AdamChrystus oraz ideę „osobowości korporatywnej”, trzeba powiedzieć, że Chrystus, jako drugi Adam, w swoim ciele dokonał zbawienia. Przy czym, używając sformułowania autora Listu do Hebrajczyków, członki tego Ciała, a więc Kościół, były „w lędźwiach praojca swego" (Hbr 7, 10). Chrystus przez chrzest przyjął owe członki w najbardziej wewnętrzną, duchowo-realną wspólnotę $\mathrm{z}$ sobą samym ${ }^{33}$.

To Ciało Chrystusa - Kościół wyposażane jest przez Ducha Świętego, sprawcę jedności poprzez chrzest (1 Kor 12, 13), w dary służące budowaniu Kościoła (por. 1 Kor 12, 4-11). Ten Kościól - Ciało Chrystusa jest posilane Eucharystią, która jedność zapoczątkowaną przez chrzest umacnia, wyraża w sposób sakramentalny i zobowiązuje do jej zachowania ${ }^{34}$. Stan tego Kościoła - Ciała Chrystusa, zjednoczonego przez Eucharystię, opisuje P. Jewdokimow: „Członki scalone są w jeden organizm, Ciało Chrystusa, w którym krąż̇y życie Boże, czyniąc wszystkich Jednym Chrystusem, zgodnie ze słowami świętego Symeona. Jedność braci, o której mówią Dzieje Apostolskie $(4,32)$, do-

\footnotetext{
${ }^{29}$ Por. P. Neuzeit, jw., s. 211.

${ }^{30}$ Por. tamże, s. 218.

31 Por. J. SCHLOSSER, Le corps en 1 Co 12, 12 - 31, [w:] Le corps et le Corps du Christ..., s. 109.

32 Tamże.

${ }^{33}$ Por. P. Neunzert, jw., s. 218.

${ }^{34}$ Por. F. HAHN, jw., s. 38 n.
} 
pełnia się przede wszystkim w Eucharystii, bo Eucharystia jest autentycznym i pełnym ukazaniem się Chrystusa. Orygenes tłumaczy to, mówiąc: 'Chrystus żyje jedynie wśród tych, co są zjednoczeni'. W ten sposób wyraźnie sformułowana zostaje koncepcja eucharystyczna Kościoła: przez uczestnictwo w Tym, który sam jeden jest święty, w Panu Jezusie, Jego Ciało otrzymuje postać 'Communio Sanctorum'"35.

Motywem najmocniejszym dla zachowania troski o jedność we wspólnocie przeżywającej Wieczerzę Pańską jest ta nowa rzeczywistość, do której weszło się przez chrzest, a która wzmacnia się przez każdorazowe „łamanie chleba”. Dlatego też każdorazowe uczestnictwo w Eucharystii zobowiązuje chrześcijanina do większej troski o jedność Kościoła - Ciała Chrystusa, którego jest członkiem.

\section{DIE TEILNAHME AM HERRENMAHL ALS AUFFORDERUNG ZUR EINHEIT NACH DEM ERSTEN KORINTHERBRIEF}

\section{Zusamenfassung}

Dieses Problem wurde an Hand von zwei Fragmenten: 1 Kor 10, 16 - 22 und 1 Kor 11, 17 34, ausgearbeitet. Aus den Aussagen des Hl. Paulus - die eine Belehrung in einem konkreten Fall der in der Gemeinde von Korinth stattgefunden hat darstellen - wurden Aufforderungen und Andentungen herausgelesen, die als Aufruf zu Einheit von den Lesern sollen vernommen werden. Die entsprechenden Elemente des Aufrufes lauten: das Wort „koinonia”, „Mein Leib für euch”, neuer Bund im Blut, „den Tod des Herrn verkünden”, Einheit durch den Altar, das Motiv des einen Brotes, Koinonia, Bildung des einen Leibes.

${ }^{35}$ P. JEwDokimow, Kościót odnowy, „Znak” 289 - 290 : 1978 s. 849. 